GLOBAL JOURNAL OF EDUCATIONAL RESEARCH VOL 16, 2017: 111-119

COPYRIGHT@ BACHUDO SCIENCE CO. LTD PRINTED IN NIGERIA. ISSN 1596-6224

www.globaljournalseries.com; Info@globaljournalseries.com

\title{
MOBILE PHONE APPLICATIONS AND THE UTILIZATION OF LIBRARY SERVICES IN THE UNIVERSITY OF CALABAR LIBRARY, CALABAR, NIGERIA
}

JAMES OGOM ODU AND EMMANUEL UBI OMINI

(Received 15, May 2017; Revision Accepted 10, July 2017)

\begin{abstract}
This study examined mobile phone apps and the utilization of library services in university of Calabar library, Nigeria. Four objectives and four hypotheses were formulated to guide the study. Survey research design was used. The population of the study constituted of all registered library users in the $2015 / 2016$ academic session. The population was 4,265 registered users. A sample of 225 registered users was selected using purposive and accidental sampling techniques. Questionnaire was the instrument used for data collection. Pearson product moment correlation analysis was employed to test the hypotheses at .05 level of significance. The findings revealed that there was a significant relationship between Tweeter apps and the utilization of library services, $\left(r=0.57^{*}, P<.05, d f=223, r-\right.$ critical=.138); there was a significant relationship between Whatsapp and the utilization of library services, $\left(r=0.47^{*}, P<.05, \mathrm{df}=223, \mathrm{r}\right.$-critical=.138); there is a significant relationship between Facebook apps and the utilization of library services, $(r=0.59 *, P<.05, \mathrm{df}=223, \mathrm{r}$-critical=.138); and there is a significant relationship between Skype apps and the utilization of library services, $\left(r=0.51^{*}, P<.0 .5\right.$, $\mathrm{df}=223$, $\mathrm{r}$-critical=.138). From the result of the study, it was recommended among others that the use of mobile phone apps as communication infrastructure should be encouraged in the University of Calabar Library.
\end{abstract}

KEYWORDS: Mobile Phone, Application, Utilization, Library Services, University.

\section{INTRODUCTION}

Developments in contemporary Nigerian libraries have witnessed another dimension in terms of acquisition, processing, storage and dissemination of information. It has offered librarians and information users' different options in carrying out library routine operations. The traditional practice in the then known library, where services could only be performed within the four walls of the library is fast becoming a thing of the past. Library services in the contemporary world can be rendered without the user visiting the library physically. This is courtesy of Information and communication Technology facilities of which the mobile phone is an example. The mobile phone applications have simplified the learning process and learning can take place at anytime and anywhere. Similarly, library services can be accessed remotely without necessarily visiting the library. This is a quasi-permanent separation of the user from the four walls of the library.

The traditional face-to-face system where a library user must be physically present to consult or access library services is no longer a prerequisite in the contemporary library environment. Thus, a user may not show up physically in the library with his question, but may digitally transmit requests to the library from a remote location. The library user will be attended to via the same media. Libraries have the responsibility of providing effective support

James Ogom Odu, College Librarian, Cross River State College of Education, Akamkpa, Nigeria.

Emmanuel Ubi Omini, Department of Library and Information Science, University of Calabar, Calabar, Nigeria. 
services to students in their dispersed locations be it within the country or outside. Being a service agency, the library normally tailored its services to reflects the vision of its parent institution by diversifying its resources and services to address the teaching, learning and research needs of staff and students, irrespective of their locations. The need to efficiently carry out its obligations and take library services to the users has brought to the fore front the desire to continuously explore mobile phone applications such as Twitter, Whatsapp, Face book, Skype and others as communication infrastructure capable of creating an interface between the library, its resources and its users.

The mobile phone, cell phone, cellular phone or handset, as it was variously called, was introduced in Nigeria in August 2001. Since its introduction, Nigeria and Nigerians have witnessed an unprecedented revolution in communication pattern with its level of sophistication and wide spread acceptance by everyone. This is because no other technology or form of communication has been so beneficial to all and sundry like the ubiquitous mobile phones. Its simplicity has facilitated its use by both the literate and the illiterate people. More so, it has remained one of the technologies to be so embraced by both the rich and the poor. It is certain that the novel but revolutionary communication infrastructure has improved lives, impacted the society, improved the economy in diverse ways and greatly enhanced interpersonal and group communications within and outside Nigeria, (Odu, 2015). The mobile phone has various applications that are used for different purposes. Essentially, all these applications are meant to enhance personal, interpersonal, group and intergroup communication. Information agencies like Libraries and Information Centre are good avenues where these Mobile Phone Applications can be used to enhance service delivery to the public. Such Applications like Twitter, Whatsapp, Face Book and Skype can be used by Libraries as the interface between the Library and the Librarys users.

Mobile Phone Applications are potential learning and research infrastructure that can be used by Libraries, Library users and other researchers for information search and retrieval. It is also a veritable tool that could be used to access Library resources and services.
Mobile phone apps access is currently being hyped as the next ICT tools that are reshaping library services with the aid of enabled mobile devices for web searches, thus, making Mobile Phone Apps the dominant form of digital interaction. Information users in today's world are on the move and they are using mobile phone application platforms to get there. It allows users to have all their information needs at the tip of their fingers. Similarly, the applications work on multiple mobile apps platforms. There are the fastest growing segment of the mobile space in higher education. No matter the type of service available in a library, a mobile app can help get and sustain users' interest as the first port of call for users to search for information products and services online. If a library service is available online and you have an app that users can download to their devices, the library will definitely be making good impression on the user'. At a glance, users will be able to assess the library through the Mobile Apps. The mobile apps are platforms for advocacy and marketing tools which could be used to convey library services to the users and also allow the users' to make their requests to different libraries, to visit the library website and to download relevant information using their mobile devices.

Library services have witnessed tremendous improvement around the globe. Information that once took several processes and procedures to obtain is now readily and easily available on the mobile phone apps. However, even when apps are commonly used, the desired impacts on library operations like current awareness services, reference services, circulation services, serial control and lending services, are being felt when they are well utilized. The use of Facebook apps for example could be used to fast track utilization of current awareness services in the library, Twitter apps on reference services, Whatsapp apps on utilization of lending services, Skype apps on utilization of exhibition and display service. These apps has radically altered the utilization of library services because of its fast and easy resource sharing techniques. University of Calabar library now share information in a wider spectrum which speed up work operations and promote cooperation.

The use of Mobile Phone Apps to access library resources and services requires availability of accessibility to electronic or virtual library. Consequently, many academic libraries in the developing countries, lately, are responding to 
the new digital environment. This has become imperative because of such trends as: rise of online instructions, globalization, people's desire for information, access to social media and networking environment anytime anywhere, (Ogbebor, 2013). In Nigeria, for instance, the Federal Government, through the Ministry of Education and the National University Commission, (NUC) introduced the National Virtual Library Project as a catalyst to digital revolution in Nigeria University Libraries. This project commenced with eleven University Libraries (of which the University of Calabar Library was one) and a model Virtual Library being established at the National University Commission as the hub, but the projects were stalled by inadequate funds, (NUC, 2001).

The University of Calabar Library on completion of its e-library commissioned it on the $19^{\text {th }}$ day of December, 2012 .The electronic library in the University of Calabar provides access to a number of electronic resources such as electronic databases, CD-ROM databases, open access journals and e-books. It has a capacity of 268 desktop computers and runs on both wired and wireless networks, (Bassey and Odu, 2015). With this development, it has been possible for library users, through the library website, have remote access to the resources and services available in the library, using the relevant access points.

The University of Calabar library serves an academic community of students, staff, lecturers and other researchers. It is possible for these categories of library users to remotely access library services from the comfort of their offices or hostel through Mobile Phone Apps and internet connectivity. With the commissioning of the elibrary section in 2012, the University of Calabar library is now in a vantage position to utilize the various ICT infrastructures to address the needs of users and to complement the deficiencies of the physical library. This makes the Mobile Phone Apps veritable research infrastructure for both the library and its users. Mobile Phone Apps is challenging the traditional way of delivering library services to users in terms of efficiency and speed which are no longer adequate in meeting up with conceptualizing information resources in libraries. Mobile phone apps technologies like Twitter transform short bursts of communication from one-on-one conversations to little news (or trivia) programs which can tune in whenever we want an update or have something to say and also have the potential to increase our awareness of the movements of our professional or social contacts.

Mobile phone apps has greatly made less difficult circulation services, exhibition services, reference services, current awareness services and lending of information resource practices in libraries. Publishers and vendors now send information through twitter on the available materials they have in stock to be assessed by the university librarians and/or acquisition librarian and approval is given as to needs of the university before supplies are made. This has improved the relationship between the university libraries and the publishers and vendors.

Facebook is a major service that is very useful in modern day Library practices which is very useful in document delivery. Information is sent to the various subject specialists that are involved in selection through Facebook platform. Through Facebook platforms, reference librarians can provide answers to users enquires without him/her travelling to find the materials. Sending and receiving massages using Facebook services is one of the quickest and fastest methods of communicating. Librarians can now send messages and also attach documents before sending oftentimes, while attempting to perform Library operations, librarians need to communicate with one another who may not be in close proximity. Facebook services have meant that distance is no longer a barrier and therefore, librarians can send messages to colleagues they are collaborating with on related issues.

Mobile phone apps therefore are essential in boosting the morale of librarians in their day-today job performance as it is also necessary to develop a positive attitude towards utilization of library services by clients. The present study examines the mobile phone apps and the utilization of library services in university of Calabar library. The motivation for this study is centered on the fact that university libraries are undergoing a paradigm shift and the transition in line with global practices. University of Calabar library is also heading towards this shift of provision of library and information services through the utilization of mobile phone apps tools by librarians occasioned by increasing demand by information users and improving librarians' job effectiveness and performances in their routine job operations. In this regard, the experiences, capacity and the infrastructure available to 
librarians in the University of Calabar needed to be assessed to determine the readiness of the University of Calabar library for the application and utilization of Mobile Phone Apps as basic ICT infrastructure for the provision and utilization of library resources and services.

\section{Statement of the problem}

Preliminary observation has shown that the university of Calabar library has, up to 2012, been totally dependent on manual method of performing their routine functions with its' attendant inadequacies which manifested in the forms of low patronage, lack of interest in utilizing library services, shortage of skilled manpower, high cost of library software and database connectivity, maintenance and constant epileptic power supply amongst others. With the commissioning of an electronic library five years ago, one would expect to see a holistic and integrated application and utilization of ICT infrastructure, of which Mobile Phone Apps are a quintessential part, in the provision and utilization of library resources and services. The problem of this study is, the relative poor patronage of library resources and services even with the e-library in place. In other words, is there any relationship between the application of Mobile Phone Apps and the extent of utilization of the University of Calabar Library?

\section{Objectives of the study}

The objective of this study was to explore mobile phone apps and the utilization of library services in the University of Calabar Library. Specifically the study intends to:

1. Determine the relationship between twitter apps and the utilization of library services;

2. Find out the relationship between whatsapp apps and the utilization of library services;

3. Examine the relationship between facebook apps and the utilization of library services;

4. Determine the relationship between skype apps and the utilization of library services.

\section{LITERATURE REVIEW}

Mobile phone apps have been regarded as important tools for users to access library resources and services. Therefore, libraries are using apps to promote the innovation of mobile information services. Mobile phone apps are software applications that are developed to function on mobile phone devices such as mobile phones, smart phones, windows phones, tablets and other mobile devices. Given the accelerated level of growth in the size of library apps, academic libraries have also taken little or no advantage of integrating the apps to suit their library services in terms of current awareness services, reference services, circulation services etc. Mobile devices allow users more flexibility in their information behavior, but also provides new opportunities for library-based services (Hinze, Chang \& Nichols, 2010).

Mobile phone apps is a rather-new and very popular tool that enables users to communicate. Studies on mobile phone apps on search behavior have being carried out. Today mobile search still only accounts for a limited amount of mobile information access by users (Church \& Smyth, 2008). It also offers a broad spectrum of opportunities to choose from when sharing information (emoticons, images and pictures, voice notes, videos and web links, and so forth). Mobile phone apps allowed its users to provide personal information and create their own digital profile. In this case, users are prompted to include a picture, a nickname and a status, where users are encouraged to describe their online identity. In recent years librarians have conducted surveys on mobile technology in libraries. In a study, Cummings, Merrill, and Borrelli (2007) conducted a survey on library patrons to find out if they are likely to access the library catalog via smallscreen devices. They discovered that $45.2 \%$ of respondents, regardless of whether they owned a device, would access the library catalog on a small-screen device. The study further finds that Mobile access to the library catalog was the most requested service in the USU student survey, although it accounted for only $16 \%$ of the responses. Cummings, et al. also discovered that the most frequent users of the catalog were also the least willing to access the catalog via mobile devices, an interesting observation that merits further research.

Chu (2013) found that a number of academic libraries were using social networking sites. The benefits of using the tools were perceived to outweigh the costs reported to be minimal. Chu indicated that the findings in the study revealed a change in librarians regarding the use of social networking tools, which appear to be moving towards favourable trend. According to $\mathrm{Chu} \&$ 
Meulemans (2013), librarians are continually exploring the latest in technologies, including MySpace and Facebook. However, he raised a concern that during his explorations on MySpace and Facebook, he saw more interaction going on between different libraries and librarians than he saw between libraries and students. He argued that interaction between the librarians and students has the potential to be extremely powerful, even if it ends up not reaching the entire constituent of students. According to the 2010 Educause Center for Applied Research (ECAR) study, 49 percent of undergraduates consider themselves mainstream adopters of technology. Locally, Utah State University students have adopted smart phones at the rate of 39.3 percent and other handheld Internet devices at the rate of 31.5 percent. These statistics indicated that skills are increasing and the technological landscape is changing quickly.

Research carried out on adapting applications to match the user's context. A First step some libraries take is to determine the library functions users want to access using smart phones. For example, students might want to access databases, access the catalogue, download citations, view a map of the library building and its physical resources, and ask a librarian for help (Seeholzer \& Salem, 2009). The users also hoped to access online public access catalogs (OPACs) in order to assist with locating items within library buildings (Broussard, Zhou \& Lease, 2010). Mills (2009) found that users wanted to select and use library resources and services from their mobile devices. Mobile applications according to Oladokun ( 2015), handheld mobile or portable devices such as smart (cell) phones, laptops, iPods etc., that are within easy reach of students in this new age, and the prevalent social media, a library should be able to utilize and exploit the platform to its full advantage, especially in the provision of library services. According to Onyango (2012), the dramatic penetration of the social networking activity in Africa was made possible by the fact that $57 \%$ of tweets are emanating from mobile devices. There is a significant change to the figures in the study of Farooqi (2013) which found that of the 1000 participants whose age ranged from 18-25 years, 640 or $64 \%$ of them were using Facebook daily for around 3-4 hours. It is palpable that within these age brackets are university students doing their diploma, degree or higher degree programmes either full-time, part-time or by distance delivery mode. One feature that endears
Facebook to its numerous 11adherents is instant messaging/chat and apps. Besides, apart from allowing its users to customize their profile, Facebook allows them to hang photos on their 'walls' or upload in albums and post videos. A librarian can open a Facebook page, which is free, and customize the use for members of his or her constituencies. The above views agrees with Daniel (2013), that mobile phone apps have allowed present day libraries to over shadow the conventional library methods.

In Hong Kong, Chu and Du (2013) investigated the use of Mobile Phone Apps in academic libraries, the extent of their use and library staff's perceptions of their usefulness and challenges. The study found that, Facebook and Twitter were considered the most successful tools. Most library staff had positive opinions on the usefulness of Social networking tools, but hesitancy among library staff and limited participation of users (i.e. students) were barriers to usage.

Previous studies reviewed have shed light on paucity of utilization of mobile phone apps on the provision of library services in the University of Calabar Library. Additionally, most studies that are somehow related were conducted outside the area of the study. This is the gap this study intends to cover. Specifically, the gap seeks to cover composite effect of mobile phone apps on the utilization of library services in the University of Calabar, Nigeria using large sample size of library users with greater emphasis on Twitter apps, Whatsapp apps, Facebook apps and Skype apps on utilization of library services. Contrary to the high-speed growth of the number of mobile phone library apps, the picture of the actual utilization by students of those apps is not optimistic. Users who actually use these apps are less than $30 \%$ of the number who have downloaded them, and only $20 \%$ of users continue to use the apps (EnfoDesk 2014). Some users even uninstalled the apps almost immediately after downloading. However, in developed countries of Europe or North America, the utilization rate of mobile phone library apps has exceeded $80 \%$ of the number of users downloading them (Yan 2013). The less utilization has continued to be a critical issue for researchers and libraries in Nigeria.

Facing the trend of fast growth of technology innovation, libraries, especially in developing countries, have started to respond to the use of ICT and its varied facilities to meet the demand of 
users. Mobile Phone Apps are an integral part of this new communication technology can be used to delivers an indispensable "any time", "any place" portal into the entire world wide web of knowledge (Boulos, Wheeler, Tavares, \& Jones, 2011, p.3). It is a good chance for libraries to establish Mobile Phone Applications to provide innovative services to their users. Mobile Phone Apps have also provided the much needed convenience for students to access learning materials and facilitate online group discussions (Lundin, Lymer, Holmquist, \& Brown, 2010), enabling them to copy notes at a faster rate using mobile phone devices like smart phones, android phones, tablets, and easing collaboration outside the classrooms (Kay \& Lauricella, 2011). For instance, mobile apps such as skype provide lecturers with the means to conduct real-time discussions from another environment or library to measure students' understanding, and generate reports of students' level of participation and collaborative discussions through video conferencing. Classroom response systems through whatsapp ("Clickers") allow lecturers to field multiple-choice questions online and students are to answer each question via online at their convenience. The benefit of using Clickers is their ability to summarize results in chart forms such as a histogram, thus allowing lecturers to know the exact percentage of students who answered correctly versus those who answered incorrectly. Lecturers can also view names of students who answered correctly and incorrectly. Tools such as Skype and Whatsapp promote interactivity by providing a platform for lecturers to gather students' responses not otherwise possible in classes with large number of students or students enrolled in online courses (Cobb, Heaney, Corcoran, \& Henderson-Begg, 2010).

\section{RESEARCH METHODOLOGY}

This study was conducted in the University of Calabar library, Nigeria. Survey research design was adopted for the study. The population of the study comprised all registered library users in the 2015/2016 session. The population was 4,265 registered users. The sampling techniques adopted for this study were the purposive and accidental sampling techniques. The choice of using purposive and accidental sampling was based on the fact that for purposive, only respondents who are judged to be registered users in the library were relevant and chosen while for accidental were only those registered users whom the researcher meet at the point of administering the questionnaires that were chosen. The sample of this study was made up of two hundred and twenty-five (225) registered users. The instrument that was used for this research was a 4-point Likert type scale questionnaire designed by the researchers. The validity and reliability of the instrument were properly ascertained.

\section{RESULTS AND FINDINGS}

The main dependent variable of the study was utilization of library services. The mean and standard deviation of the major variables of the study are calculated and presented as shown below. A total of two hundred and twenty-five (225) respondents were used for the study.

Table 1: General description of data

\begin{tabular}{lccc}
\hline Variables & $\mathbf{N}$ & $\mathbf{X}$ & SD \\
\hline Twitter apps & 225 & 16.93 & 1.12 \\
Whatsapp apps & 225 & 16.06 & 1.88 \\
Facebook apps & 225 & 17.47 & 2.20 \\
Skype apps & 225 & 16.53 & 1.59 \\
Utilization of Library services & 225 & 21.27 & 1.84
\end{tabular}

The following null hypothesis were formulated and tested at .05 level of significance and 223 degree of freedom.

\section{Hypothesis one:}

There is no significant relationship between Twitter apps on the utilization of library services.

The independent variable involve in this hypothesis is Twitter apps, while the dependent variable is utilization of library services. Pearson product correlation analysis was employed to test this hypothesis. The result of the analysis is presented in Table 2. The result in Table 2 reveals that the calculated r-value of 0.57 is higher than the critical r-value of .138 at .05 level of significance with 223 degrees of freedom. With this result the null hypothesis was rejected. This result therefore means that Twitter apps has a significant relationship with the utilization of library services. 
Table 2: Pearson product moment correlation analysis of the relationship between Twitter apps and the utilization of library services $(\mathrm{N}=225)$

\begin{tabular}{|c|c|c|c|}
\hline Variables & $\sum_{\sum \mathrm{x}} \mathrm{x}$ & $\begin{array}{l}\sum \mathrm{x} 2 \\
\sum \mathrm{y} 2\end{array}$ & Exyr-value \\
\hline Twitter Apps & 3218 & 6297 & \\
\hline Utilization of Library Services & 3092 & 5463 & $747130.57^{*}$ \\
\hline
\end{tabular}

${ }^{*}$ Significant at .05 level, critical $r=.138, \mathrm{df}=223$

Hypothesis two:

There is no significant relationship between Whatsapp apps and utilization of library services.

The independent variables involve in this hypothesis is Whatsapp apps, while the dependent variable is utilization of library services. Pearson product correlation analysis was employed to test this hypothesis. The result of the analysis is presented in Table 3 . The result in Table 3 reveals that the calculated r-value of 0.47 is higher than the critical r-value of .138 at .05 level of significance with 223 degrees of freedom.

With this result the null hypothesis was rejected. This result therefore means that Whatsapp apps has a significant relationship with the utilization of library services.

Table 3: Pearson product moment correlation analysis of the relationship between Whatsapp apps and The utilization of library services $(\mathrm{N}=225)$

\begin{tabular}{|c|c|c|c|}
\hline Variables & $\sum x$ & $\begin{array}{l}\sum x 2 \\
\sum y 2\end{array}$ & Exyr-value \\
\hline Whatsapp apps & 3376 & 6375 & \\
\hline Utilization of library services & 3092 & 5463 & $739260.47^{*}$ \\
\hline
\end{tabular}
${ }^{*}$ Significant at .05 level, critical $r=.138, \mathrm{df}=223$

Hypothesis three:

There is no significant relationship between Facebook apps and the utilization of library services.

The independent variables involve in this hypothesis is Facebook apps; while the dependent variable is utilization of library services. Pearson product correlation analysis was employed to test this hypothesis. The result of the analysis is presented in Table 4.

Table 4: Pearson product moment correlation analysis of the influence of Facebook apps and the utilization of library services $(\mathrm{N}=225)$

\begin{tabular}{lccc}
\hline \multirow{2}{*}{ Variables } & $\sum x$ & $\sum x 2$ & \\
Facebook apps & $\sum y$ & $\sum y 2$ & $\sum x y r-v a l u e$ \\
& 3176 & 6154 & \\
Utilization of library services & 3092 & 5463 & $746470.59^{*}$ \\
\hline \multicolumn{4}{l}{${ }^{*}$ Significant at .05 level, critical $r=.138, \mathrm{df}=223$}
\end{tabular}

The result in Table 4 reveals that the calculated r-value of 0.59 is higher than the critical r-value of .138 at .05 level of significance with 223 degrees of freedom. With this result the null hypothesis was rejected. This result therefore means that 
Facebook app shas a significant relationship with the utilization of library services.

\section{Hypothesis four:}

There is no significant relationship between Skype apps and utilization of library services.

The independent variable in this hypothesis is Skype apps; while the dependent variable is utilization of library services. Pearson product moment correlation analysis was employed to test this hypothesis. The result of the analysis is presented in Table 5 . The result in Table 5 reveals that the calculated r-value of 0.51 is higher than the critical r-value of .138 at .05 level of significance with 223 degrees of freedom. With this result the null hypothesis was rejected. This result implies that Skype apps has a significant relationship with the utilization of library services.

Table 6: Pearson product moment correlation analysis of the relationship between Skype apps and the utilization of library services $(\mathrm{N}=225)$

\begin{tabular}{llll}
\hline Variables & $\sum x$ & $\sum x 2$ & \\
Skype apps & $\sum y$ & $\sum y 2$ & $\sum x y r-v a l u e$ \\
& 3262 & 6344 & \\
Utilization of library services & 3092 & 5463 & \\
\hline
\end{tabular}

*Significant at .05 level, critical $r=.138, \mathrm{df}=223$

\section{CONCLUSION}

Based on the results of the study, it was concluded that mobile phone apps - Twitter, Whatsapp, Facebook and Skype generally have significant relationship with the utilization of library services in the University of Calabar. There is need for users to keep up with the positive patronage of mobile phone apps and the utilization of library services.

\section{RECOMMENDATIONS}

Based on the findings of the study the following recommendations were made.

1. Mobile phone apps should be encouraged in the University of Calabar Library Services.

2. Workshops should be organize to educate library staff and students on the importance of utilization of mobile phone apps on their information quest as it is durable, fast and easy to use.

3. Library staff and students should be encouraged to develop a positive attitude towards the utilization of mobile phone apps in teaching and learning processes.

\section{REFERENCES}

Boulos, M. N. K., Wheeler, S., Tavares, C and Jones, R., 2011. How smartphones are changing the face of mobile and participatory healthcare: An overview, with example from eCAALYX. BioMedical Engineering OnLine, 10(24).
Broussard, R., Zhou, Y and Lease, M., 2010. University of Texas mobile library search. Proceedings of the American Society for Information Science and Technology, 47(1), 1-2.

Chu, M and Meulemans, Y. N., 2013. The problems and potential of MySpace and Facebook usage in academic libraries. Internet Reference Services Quarterly, 13(1), 69-85.

Church, K., Smyth, B., Cotter, P and Bradley, K., 2007. Mobile Information Access: A Study of Emerging Search Behavior on the Mobile Internet. ACM Trans. Web 1, 1(May, 2007), 1-38.

Church, K and De Oliveira, R., 2013. What's up with whatsapp? Comparing mobile instant messaging behaviors with traditional SMS. Proceedings of the 15th International Conference on Humancomputer Interaction with Mobile Devices and Services (pp. 352-361). ACM.

Cobb, S., Heaney, R., Corcoran, $\mathrm{O}$ and Henderson-Begg, S., 2010. Using mobile phones to increase classroom interaction. Journal of Educational Multimedia and Hypermedia, 19 (2), 147-157.

Cummings, J., Merrill, A and Borrelli, S., 2007. 
The Use of Handheld Mobile Devices: Their Impact and Implications for Library Services. Library Hi Tech. Vol. 28 (1), 22-40.

Daniel, A., 2013. Using mobile instant messaging to leverage learner participation and transform pedagogy at a South African University of Technology. British Journal of Educational Technology, 44(4), 544561.

EnfoDesk. 2014. China Mobile Reading Industry Research Report. Accessed October 6, 2016, 2014. http://www.enfodesk.com/SMinisite/maini nfo/meetingdown-id-102.pdf.

Farooqi, H., et al. 2013. Effect of Facebook on the life of medical university students. International Archives of Medicine. 6 (1):40 - 61 Available at: http://www.ncbi.nlm.nih.gov/pubmed/241 34850

Hinze, A. M., Chang, C., Nichols, D. M., 2010. Contextual queries and situated information needs for mobile users. Retrieved May 25, 2013 from http://www.cs.waikato.ac.nz/puts/wp/201 0/uow-cs-wp-2010-01.pdf

Kay, R. H and Lauricella, S., 2011. Exploring the benefits and challenges of using laptop computers in higher education classrooms: A formative analysis. Canadian Journal of Learning and Technology, 37 (1), 1-18.

Lipsmoin, L. N., 2007. The social use of electronic communication at a major university. Computers and the Social Sciences, 1, 191-197.

Lundin, J. Lymer, G., Holmquist, L. E and Brown, B., 2010. Integrating students' mobile technology in higher education. International Journal of Mobile Learning and Organisation, 4 (1), 1-14.

Marmasse, $\mathrm{N}$ and Schmandt, C., 2000. Locationaware information delivering with commotion. Proc HUC 2000, pp.157-171.

Mihalic, K and Tscheligi, M., 2007. Divert motherin-law' representing and evaluating social context on mobile devices. Proceedings of the 9thinternational conference on human computer interaction with mobile devices and services. MobileHCl 2007, pp.257- 264.

Mills, K., 2009. M-Libraries: Information use on the move. Retrieved Aug. 30, 2013 from l/;http://www.dspace.cam.ac.uk/handle/1 $810 / 221923$

Ogbebor, I., 2013. WhatsApp with BlackBerry: Can Messengers (BBM) be MXit?. In Proceedings of the 14th Annual Conference on World Wide Web Applications. Cape Peninsula University of Technology, Cape Town, South Africa.

Oladokun, O., 2015. The Potential and Utilization of Social Media in Library and Information Centres. In A. Tella (Ed.), Social Media Strategies for Dynamic Library Service Development. Hershey, PA: Information Science Reference. (pp. 24-40). doi:10.4018/978-1-4666-74158.ch002

Onyango, E., 2012. 'Kenyans second top tweeters in Africa', Daily Nation, 26 January viewed 7 March 2013, from http://www.nation.co.ke/Tech/Kenyanssecondtoptweeters-in-Africa//1017288/1314162/-/ux3kf3/-/index.html

Seeholzer, J and Salem, J. A., 2009. Library on the go: A focus group study of the mobile web and the academic library. College \& Research Libraries, 72(1), 19-20.

Shannon D. S. and Judith B. C., 2010. An introduction by Joshua Kim, The ECAR Study of Undergraduate Students and Information Technology. Boulder, CO: Education Center for Applied Research, 6 www.educause.edu/ecar (accessed October. $\left.5^{\text {th }}, 2016\right)$.

Yan, L., 2013. APP Mobile Services of Libraries at Home and Abroad: Comparative Analysis and Enlightenment. Information and Documentation Services 23 (6):858. 
